\title{
41SM195A, The Browning Site
}

\section{Mark Walters}

Heritage Research Center, Stephen F. Austin State University

Follow this and additional works at: https://scholarworks.sfasu.edu/ita

Part of the American Material Culture Commons, Archaeological Anthropology Commons, Environmental Studies Commons, Other American Studies Commons, Other Arts and Humanities Commons, Other History of Art, Architecture, and Archaeology Commons, and the United States History Commons

Tell us how this article helped you.

This Article is brought to you for free and open access by the Center for Regional Heritage Research at SFA ScholarWorks. It has been accepted for inclusion in Index of Texas Archaeology: Open Access Gray Literature from the Lone Star State by an authorized editor of SFA ScholarWorks. For more information, please contact cdsscholarworks@sfasu.edu. 


\section{SM195A, The Browning Site}

Creative Commons License

(c) (i) (8)

This work is licensed under a Creative Commons Attribution-NonCommercial 4.0 International License 


\title{
41SM195A, The Browning Site
}

\author{
Mark Walters
}

A surface collection of early $19^{\text {th }}$ century historic sherds led to archeological investigations in 2002 and 2003 at the Browning site (41SM195A) in Smith County, Texas. My interest was whetted by mention in the original land abstract that the property had once been deeded to the Cherokee (Walters 2003) In all, a total of 6.5 cubic meters was excavated, including twenty-two shovel tests and $101 \times 1 \mathrm{~m}$ test units, and a fine-screen sample was taken from the midden. As a result, 1076 prehistoric and historic artifacts were recovered, along with new information about the Woodland period archeology in this part of East Texas.

The initial shovel tests found, in addition to the historic component, a buried midden with evidence of Woodland period occupation. Based on the excavations, the midden covered approximately $500 \mathrm{~m}^{2}$. The $19^{\text {th }}$ century historic artifacts were found in the upper sediment zone (a light brown sandy loam that was mostly gravel-free) covering the midden. The buried midden was a dark yellowish-brown gravelly loam that contained prehistoric pottery, bone, charred wood and nutshells, lithic materials, including lithic debris, flake tools, arrow and dart points, and ground stone tools. A calibrated radiocarbon date of AD 625 to 880 (2 sigma), with a calibrated intercept of AD 685, was obtained on charred nutshell from $40-50 \mathrm{~cm}$ bs in the midden zone. A series of Oxidizable Carbon Ratio dates from the midden indicate that the midden began to form about AD 147, with dates of AD 359-817 from the main part of the midden, indicating when the Browning site was most intensively occupied in prehistoric times.

The prehistoric (and historic) components are confined to a small corner of a $3800 \mathrm{~m}^{2}$ terrace that overlooks the Auburn Creek floodplain; an undulating sandstone bedrock is the parent material and is exposed on the margins of the landform. Depth to the sandstone varies from 30 $\mathrm{cm}$ bs to more than $70 \mathrm{~cm}$ bs across the 12 meter length of the test units. This terrace was probably truncated at some earlier time and the present soils, excluding the recent relatively sterile overburden, developed from this sandstone parent material. Where present, the midden extends to this sandstone layer. A $20 \mathrm{~cm}$ thick layer of overburden, as indicated by particle size analysis, caps the midden. The origins of this soil are unknown but it could be colluvial or eolian in nature. There is also the possibility that this layer could be the result of earthworms bringing finer materials to the surface, gradually covering up the midden zone.

No definite conclusions could be reached about the function of the historic component at the Browning site, other than to note that the recovered artifacts-principally ceramics - indicate that it was occupied prior to the Civil War. The decorated whiteware ceramics include annular ware and blue shell-edge, and there are also a few yellowware sherds. A small concentration of ash and fired clay in one excavation unit may mark a possible chimney location.

Woodland period sites are not well known or documented in this part of East Texas. The role that the Woodland period cultures played in the development after ca. A.D. 900 of the later Caddo culture has been a question that was addressed at the 2003 East Texas Archeological Conference in Texarkana, Texas, but much work remains to be done before any definitive answers can be provided on how the two cultures relate to one another.. 
Prehistoric artifacts collected from the Browning site include eight plain grog- and grog/ bone-tempered sherds, and they averaged $8.8 \mathrm{~cm}$ in thickness. They were collected in the midden zone between 20-60 cm bs. One sherd had a contorted paste but all had smooth surfaces and had been well-fired. Five of the sherds did have a sandy paste. Two sherds were submitted for instrumental neutron activation analysis (INAA) to determine the probable source or source zone of the clays used in the manufacture of the vessel sherds, and this INAA work is in progress at the Missouri University Research Reactor..

The 842 lithic artifacts include 16 arrow points, preforms, and fragments. Recognizable arrow points were the Friley type, and most of the arrow points were recovered between 30-50 $\mathrm{cm}$ bs. There were also five small dart points, including contracting stem Gary points. They were mostly heavily reworked and found scattered at various depths from $10-70 \mathrm{~cm}$ bs.

Most of the chipped stone tools and lithic debris were from red and gray local quartzite and petrified wood. There were three small groundstone tools made from local sandstone that were probably used in plant processing. A fine screen sample was submitted for floral analysis and the finding indicate that domesticated plant remains were not present, and that the subsistence economy was based on the gathering of local plant resources, of which nuts were the main item. A total of 43 grams of charred nutshell was collected from the Browning site excavations. Other plant remains include 31 grams of charred wood, but no seeds. Since little information is available on the character of Woodland period diets in East Texas, the 88 pieces of animal bone were also submitted for analysis. The animal bones indicate that the diet was supplemented with large game such as deer.

In summary, the Browning site represents a pre-Civil War habitation site, probably of short duration, and an intact buried Woodland period component with a small midden deposit. No evidence of prehistoric agricultural activities is apparent in the archeological deposits, and the faunal and floral remains point to a foraging lifestyle that was reliant on the collecting and processing of native plants and animals. No evidence of a structure was found at the site, but the remains of a good-sized midden indicate that the site was used for extended periods of time during the lengthy Woodland period. A small amount of plain prehistoric pottery was also found in the midden deposits, perhaps being indicative of a more sedentary lifestyle during some part of the Browning site occupation. The small amount collected, and its low density, however are from a very limited use of pottery vessels at this time, as these were probably restricted to occasional cooking activities.

\section{References Cited}

Walters, M.

2003 The Wolf Site (41SM195), Smith County, Texas. Journal of Northeast Texas Archaeology 18:1-21. 